\title{
Assessment of Socio Economics Status of Tribal Farmers in Chikhaldara Tehasil of Amravati District
}

\author{
S. G. Zalte*, S. M. Bhoyar and P. W. Deshmukh \\ Department of Soil Science and Agril. Chemistry, Dr. Panjbrao Deshmukh Krishi Vidyapeeth, \\ Akola, M.S., India \\ *Corresponding author
}

Keywords

Tribal, Rainfed, illiterate, Agriwastes, Fuelwood, agroforestry

Article Info

\section{Accepted:}

20 January 2021

Available Online:

10 February 2021

\section{A B S T R A C T}

The study was carried out in the Chikhaldara tehasil of Amravati District under Dr. Panjabrao Deshmukh Krishi Vidhyapeeth, Akola during the year 20152018. The study covered whole tribal area and selected 90 farmers from different villages of Chikhaldara tehasil. In the study area data were collected through field visits (direct observations) and personal interview with the sampled farmers. Among 90 farmers 25 farmers which were belongs to marginal, 23 farmers small, 24 farmers semi medium to medium, 16 farmers medium and 2 farmers are large. In study area $54.44 \%$ farmers follow rainfed agriculture practice. The majority of farmers $(47.78 \%)$ are the middle age group fallowed young age category $(21.11 \%)$. Overall majority of farmers $(44.44 \%)$ are illiterate. One third of farmers have open well as source of irrigation followed by Nala lifting irrigation (16.67\%). Overall $91.11 \%$ farmers fulfill their fuel need by collection of fuel wood from farm land that is agriwaste like tur stalk, jowar stubble etc. followed by collection of fuel wood from forest $(80 \%)$. Overall in Chikhaldhra bund planting was the major agroforestry practice $(68.89 \%)$ followed by the boundary planting $(60.00 \%)$.

\section{Introduction}

Amravati district in Maharashtra comes under Western Vidarbha agroclimatic zone and the major portion of it is known as Melghatrange means "meeting places of ghats". Melghat region lies between $20^{\circ} 51^{\prime}$ to $21^{\circ} 46^{\prime}$ North latitudes and $76^{\circ} 38^{\prime}$ to $77^{\circ} 33^{\prime}$ East longitudes. The Melghat area spread over two tehasil that is Chikhaldara and Dharni tehasil of 3970 sq. $\mathrm{km}$ area. Out of that 2200 sq. $\mathrm{km}$. area is protected under Melghat Tiger Reserve and it includes five protected areas under unified control (Bhogaonkar et al., 2010). The protected areas are Gugamal National Park, Melghat Wildlife Sanctuary, Narnala Wildlife Sanctuary, Wan Wildlife Sanctuary and Ambabarwa Wildlife 
Sanctuary. Melghat region have about 314 inhabited villages. Korku is the predominant tribe in the region comprising of 89.27 per cent of the tribal population, others amongst the tribes are Gond, Bhil, Nihal, Mongia, Rathya, Balai, Wanjari, Gawali etc. Their dialect is Korku but Hindi is also commonly spoken language among them. Traditionally Korkus had been drawing their sustenance mainly by engaging themselves in forest produce harvesting works for a period of almost one century. For them, agriculture is supplementary activity.

Chikhaldara is mainly well known for famous hill station with geographical area $2507.50 \mathrm{sq}$. $\mathrm{km}$ in Amravati district. The total out of which $81.71 \%$ area are covered under forest and total inhabited village in Chikhaldara tehasil are 169. The highest elevation point being Vairat at a height of $1188 \mathrm{mts}$, this is steep slope area zone which is hilly and occupied by mountain Satpura, land is extremely sloppy. Soils are very shallow to shallow. Kharif sorghum, soybean, minor millets and rice in some patches are the important crops of this region. This tract gives good scope for development of dry land horticulture and forage crops. The average annual rainfall at chikhaldara1540 $\mathrm{mm}$. The rainfall at Chikhaldara and other hilly areas of the district is about twice as much as in the plains. The length of growing period is 90-150 days(FSI, 2013). The mean maximum and minimum temperature have been recorded as $22^{\circ} \mathrm{C}$ and $13^{\circ} \mathrm{C}$, respectively.

\section{Materials and Methods}

Primary data was collected by informal interviews, discussion with key villagers and personal observations in around the field. Data were collected through field visits (direct observations) in the study area and personal interview with the sampled farmers. Interviews were normally conducted in farmer's house in their leisure time and even in the field when they work in the plots. Overall 90 farmers were selected from different villages of Chikhaldara tehasil. Secondary data was collected from Talathi offices of selected villages, government reports, forest department record and the relevant websites to make better understanding, interpretation and analysis of the research. The secondary data is important in understanding forest tree and also plays an important role in understanding the local geographical, social and economic situation in Melghat.

The agroforestry or forest tree plantation systems prevalent in study area were identified by visiting on farmlands. The data collected from various aspects related to the constraints in adoption of agroforestry was expressed in terms of per cent response from the respondents. The following are the villages which are selected for study. The data were analyze according to various aspect i.e. family structure, literacy, livestock status, land holding size and farming system etc.

\section{Results and Discussion}

Total 90 respondents were selected from different villages and on the basis of average size of land holding 90 farmers were categorized in marginal (up to $1 \mathrm{ha}$ ), small (1.1 to 2 ha), semi medium to medium (above 2 to $4 \mathrm{ha}$ ), medium (4 to $10 \mathrm{ha}$ ) and large (above 10 ha) size group (Table 1).

\section{Land holding size of selected farmers}

The data presented in table 2 and depicted in fig. 1 revealed that, on the basis of average size of land holding 90 farmers were categorized in which 25 farmers belongs to marginal size group, 23 farmers belong to small size group, 24 farmers belongs to semi medium to medium size group 16 farmers belongs to medium size group and 2 farmers 
belongs to large size group. The average size of land holding of selected farmers in marginal, small, semi medium, medium and large were 0.96 ha, 1.84 ha, 2.93 ha, 4.88 ha and 12 ha respectively. The overall level average size of holding is 2.65 hectare. Similar findings also reported by Chauhan et al., (1990) and Verma (1990).

\section{Distribution of farmers according to} rainfed and irrigated agriculture practices

The data given in table 3 revealed that, 54.44 per cent farmers follow rainfed agriculture practice, 23.33 per cent farmers follow irrigated agriculture practices and 22.22 per cent farmers follow both rainfed and irrigated agriculture practices in study area.

\section{Age of the selected farmers}

The data presented in table 4 and depicted in fig. 2 revealed that, the majority of farmers $(47.78 \%)$ are the middle age group followed by 31.1 per cent in old age category. Similar observations also made by Dwivedi et al., (2010).

\section{Educational status of selected farmers}

Education is important aspects which affect standard of living of farmers in adoption of new technologies and so on. The information regarding the education status of farmers is presented in table 5 and depicted in fig. 3.

Overall majority of farmers (44.44\%) are illiterate followed, by primary school level education $(17.78 \%)$ and above $10^{\text {th }}$ level education (16.67\%). Among the semi medium category of farmers, illiterate farmers which are highest in numbers $(54.17 \%)$ whereas, among small farmer highest number of $(43.48 \%)$ farmers are illiterate followed by middle school level educated farmers $(21.74 \%)$. Similar observations also made by
Verma (1990) and Singh et al., (1996). In Melghat, most of the tribal, scheduled casts and poor children do not have access to the basic education. The poor condition of the tribal schools, the extreme poverty, blind belief in rituals and child marriage were hampering the Educational improvement of the tribal people. Overall literacy rate in Chikhaldara tehasil is less than the district average (Adhau, 2015).

\section{Land utilization pattern of selected farmers (on an average)}

It is observed land utilization pattern of selected farmers are presented in from table 6 that, the average land holding in respect of marginal, small, semi medium, medium and large size group was 0.96 ha, 1.84 ha, 3.13 ha, 4.88 ha and 12.00 ha respectively.

\section{Sources of irrigation in selected farmers}

The details of sources of irrigation are presented in table 7 and depicted in fig. 4 . The irrigation facilities in Chikhaldhara of Melghat are limited because there is no any large irrigational project and irrigation is primarily through open well. The farmers who do not have any irrigation facility they take irrigation facility on rent from other farmer. Similar findings also reported by Verma (1990). Table 7 shows that, near about one third of the respondents have openwell as source of irrigation followed by Nala lifting irrigation (16.67\%),rent based irrigation (13.33), river lifting (8.89\%), Pond (8.33\%), Tube well $(8.89 \%)$. In the marginal group, 40.00 per cent farmers are water sources on rent, 16.00 per cent farmers are having open well. In small group of farmer 43.48 per cent farmers having open well, 17.39 per cent have tube well and also 21.74per cent farmers are using nala lifting for irrigation. 
Table.1 Geo-referencing of selected village for study area

\begin{tabular}{|c|c|c|c|c|}
\hline Sr. No. & Name of Village & Latitude & Longitude & MSL (Meter) \\
\hline $\mathbf{1 )}$ & Sawarya & $21^{0} 25.982$ & $77^{0} 01.992$ & 387 \\
\hline $\mathbf{2 )}$ & Aadhao & $21^{0} 25.690$ & $77^{0} 05.861$ & 424 \\
\hline $\mathbf{3 )}$ & Korda & $21^{0} 136.086$ & $77^{0} 31.222$ & 838 \\
\hline $\mathbf{4 )}$ & Chunkhadi & $21^{0} 34.486$ & $77^{0} 25.068$ & 759 \\
\hline $\mathbf{5 )}$ & Makhala & $21^{0} 31.981$ & $77^{0} 22.912$ & 948 \\
\hline $\mathbf{6 )}$ & Motha & $21^{0} 24.104$ & $77^{0} 22.337$ & 1031 \\
\hline $\mathbf{7 )}$ & Hirdamal & $21^{0} 38.183$ & $77^{0} 31.566$ & 604 \\
\hline $\mathbf{8 )}$ & Telkhar & $21^{0} 19.173$ & $77^{0} 20.322$ & 582 \\
\hline $\mathbf{9 )}$ & Beriteki & $21^{0} 26.360$ & $77^{0} 00.310$ & 379 \\
\hline $\mathbf{1 0})$ & Katkum & $21^{0} 34.095$ & $77^{0} 32.734$ & 850 \\
\hline $\mathbf{1 1 )}$ & Churni & $21^{0} 37.508$ & $77^{0} 30.956$ & 771 \\
\hline $\mathbf{1 2})$ & Aaladoh & $21^{0} 23.927$ & $77^{0} 20.509$ & 1077 \\
\hline $\mathbf{1 3 )}$ & Badnapur & $21^{0} 21.186$ & $77^{0} 22.317$ & 550 \\
\hline $\mathbf{1 4 )}$ & Dharmdhao & $21^{0} 18.269$ & $77^{0} 18.319$ & 522 \\
\hline $\mathbf{1 5})$ & Tembhursonda & $21^{0} 18.646$ & $77^{0} 18.616$ & 537 \\
\hline
\end{tabular}

Table.2 Distribution of farmers according to size of land holding.

\begin{tabular}{|c|c|c|c|}
\hline Sr.No. & Size of land holding & Farmers selected & Average size of land holding (ha) \\
\hline $\mathbf{1}$ & $\begin{array}{c}\text { Marginal } \\
\text { (up to 1 ha) }\end{array}$ & 25 & 0.96 \\
\hline $\mathbf{2}$ & $\begin{array}{c}\text { Small } \\
\text { (1.1 to 2 ha) }\end{array}$ & $\begin{array}{c}27.78) \\
23\end{array}$ & 1.84 \\
\hline $\mathbf{3}$ & Semi medium to medium ( 2 to 4 & $(25.56)$ & 2.93 \\
\hline $\mathbf{4}$ & $\begin{array}{c}\text { ha) } \\
\text { (4 to 10 ha) }\end{array}$ & $(26.27)$ & 4.88 \\
\hline $\mathbf{5}$ & $\begin{array}{c}\text { Large } \\
\text { (above 10 ha) }\end{array}$ & $(16.78)$ & 12.00 \\
\hline $\mathbf{6}$ & Total & 2 & 2.65 \\
\hline
\end{tabular}

(Figures in parenthesis indicate the percentage to total)

Table.3 Distribution of farmers according to rainfed and irrigated agriculture practices

\begin{tabular}{|c|c|c|c|c|c|c|c|}
\hline $\begin{array}{c}\text { Sr. } \\
\text { No. }\end{array}$ & $\begin{array}{c}\text { Agriculture } \\
\text { practices }\end{array}$ & $\begin{array}{c}\text { Marginal } \\
(\mathbf{n = 2 5})\end{array}$ & $\begin{array}{c}\text { Small } \\
(\mathbf{n = 2 3})\end{array}$ & $\begin{array}{c}\text { Semi medium to } \\
\text { medium }(\mathbf{n = 2 4})\end{array}$ & $\begin{array}{c}\text { Medium } \\
(\mathbf{n = 1 6})\end{array}$ & $\begin{array}{c}\text { Large } \\
(\mathbf{n = 2})\end{array}$ & $\begin{array}{c}\text { Total } \\
(\mathbf{n = 9 0})\end{array}$ \\
\hline $\mathbf{1 .}$ & Irrigated & $\begin{array}{c}4 \\
(16.00)\end{array}$ & $\begin{array}{c}7 \\
(30.43)\end{array}$ & $\begin{array}{c}7 \\
(29.17)\end{array}$ & $\begin{array}{c}3 \\
(18.00)\end{array}$ & $\begin{array}{c}(00) \\
(23.33)\end{array}$ \\
\hline $\mathbf{2 .}$ & Rainfed & 21 & 9 & 9 & 8 & 2 & 49 \\
$(84.00)$ & $(39.13)$ & $(37.50)$ & $(50.00)$ & $(100)$ & $(54.44)$ \\
\hline 3. & Both (Irrigated & 0 & 7 & 8 & 5 & 0 & 20 \\
& and Rainfed) & $(00)$ & $(30.43)$ & $(33.33)$ & $(31.25)$ & $(00)$ & $(22.22)$ \\
\hline
\end{tabular}


Int.J.Curr.Microbiol.App.Sci (2021) 10(02): 2655-2666

Table.4 Distribution of farmers according to their age

\begin{tabular}{|c|c|c|c|}
\hline \multirow{2}{*}{ Sr. No. } & Category (years) & \multicolumn{2}{|c|}{ Selected farmers (n=90) } \\
\cline { 3 - 4 } & & Number & Percentage \\
\hline $\mathbf{1}$ & Young (Up to 35) & 19 & 21.11 \\
\hline $\mathbf{2}$ & Middle (36 to 50) & 43 & 47.78 \\
\hline $\mathbf{3}$ & Old (Above 50) & 28 & 31.11 \\
\hline $\mathbf{4}$ & Total & 90 & 100 \\
\hline
\end{tabular}

(Figures in parenthesis indicate the percentage to total)

Table.5 Distribution of farmers according to their educational level

\begin{tabular}{|c|c|c|c|c|c|c|c|}
\hline Sr.No. & Particulars & $\begin{array}{c}\text { Marginal } \\
(n=25)\end{array}$ & $\begin{array}{c}\text { Small } \\
(n=23)\end{array}$ & $\begin{array}{c}\text { Semi medium to } \\
\text { medium }(n=24)\end{array}$ & $\begin{array}{c}\text { Medium } \\
(\mathrm{n}=16)\end{array}$ & $\begin{array}{c}\text { Large } \\
(n=2)\end{array}$ & $\begin{array}{c}\text { Total } \\
(n=90)\end{array}$ \\
\hline 1 & Illiterate & $\begin{array}{c}10 \\
(40.00)\end{array}$ & $\begin{array}{c}10 \\
(43.48)\end{array}$ & $\begin{array}{c}13 \\
(54.17)\end{array}$ & $\begin{array}{c}6 \\
(37.50)\end{array}$ & $\begin{array}{c}1 \\
(50.0)\end{array}$ & $\begin{array}{c}40 \\
(44.44)\end{array}$ \\
\hline 2 & $\begin{array}{l}\text { Primary school } \\
\left(1 \text { to } 4^{\text {th }}\right)\end{array}$ & $\begin{array}{c}41 \\
(6.00)\end{array}$ & $\begin{array}{c}3 \\
(13.04)\end{array}$ & $\begin{array}{c}5 \\
(20.83)\end{array}$ & $\begin{array}{c}3 \\
(18.75)\end{array}$ & $\begin{array}{c}1 \\
(50.0)\end{array}$ & $\begin{array}{c}16 \\
(17.78)\end{array}$ \\
\hline 3 & $\begin{array}{l}\text { Middle school } \\
\left(5^{\text {th }} \text { to } 7^{\text {th }}\right)\end{array}$ & $\begin{array}{c}6 \\
(24.00)\end{array}$ & $\begin{array}{c}3 \\
(13.04)\end{array}$ & $\begin{array}{c}0 \\
(00.00)\end{array}$ & $\begin{array}{c}2 \\
(12.50)\end{array}$ & $\begin{array}{c}0 \\
(00.0)\end{array}$ & $\begin{array}{c}11 \\
(12.22)\end{array}$ \\
\hline 4 & $\begin{array}{l}\text { High school } \\
\left(8^{\text {th }} \text { to } 10^{\text {th }}\right)\end{array}$ & $\begin{array}{c}1 \\
(4.00)\end{array}$ & $\begin{array}{c}2 \\
(8.70)\end{array}$ & $\begin{array}{c}2 \\
(8.33)\end{array}$ & $\begin{array}{c}3 \\
(18.75)\end{array}$ & $\begin{array}{c}0 \\
(00.0)\end{array}$ & $\begin{array}{c}8 \\
(8.89)\end{array}$ \\
\hline 5 & Above $\left(10^{\text {th }}\right)$ & $\begin{array}{c}4 \\
(16.00)\end{array}$ & $\begin{array}{c}5 \\
(21.74)\end{array}$ & $\begin{array}{c}4 \\
(16.67)\end{array}$ & $\begin{array}{c}2 \\
(12.50)\end{array}$ & $\begin{array}{c}0 \\
(00.0)\end{array}$ & $\begin{array}{c}15 \\
(16.67)\end{array}$ \\
\hline 6 & Total & $\begin{array}{c}25 \\
(100.00)\end{array}$ & $\begin{array}{c}23 \\
(100.00)\end{array}$ & $\begin{array}{c}24 \\
(100.00)\end{array}$ & $\begin{array}{c}16 \\
(100.00)\end{array}$ & $\begin{array}{c}2 \\
(100.00)\end{array}$ & $\begin{array}{c}90 \\
(100.00)\end{array}$ \\
\hline
\end{tabular}

(Figure in parenthesis indicate the percentage to total) 
Table.6 Distribution of farmers according to their land utilization pattern (Area in ha)

\begin{tabular}{|c|c|c|c|c|c|c|c|}
\hline $\begin{array}{l}\text { Sr. } \\
\text { No. }\end{array}$ & Particulars & $\begin{array}{c}\text { Marginal } \\
(\mathbf{n}=25)\end{array}$ & $\begin{array}{l}\text { Small } \\
(n=23)\end{array}$ & $\begin{array}{c}\text { Semi } \\
\text { medium to } \\
\text { medium } \\
(n=24)\end{array}$ & $\begin{array}{l}\text { Medium } \\
(\mathrm{n}=16)\end{array}$ & $\begin{array}{c}\text { Large } \\
(n=2)\end{array}$ & $\begin{array}{c}\begin{array}{c}\text { Overal } \\
\text { Total } \\
(n=90)\end{array} \\
\text { (n) }\end{array}$ \\
\hline 1 & $\begin{array}{l}\text { Average size of } \\
\text { land holding }\end{array}$ & $\begin{array}{c}0.96 \\
(100)\end{array}$ & $\begin{array}{c}1.84 \\
(100)\end{array}$ & $\begin{array}{c}3.13 \\
(100)\end{array}$ & $\begin{array}{l}4.88 \\
(100)\end{array}$ & $\begin{array}{l}12.00 \\
(100)\end{array}$ & $\begin{array}{c}2.70 \\
(100)\end{array}$ \\
\hline 2 & $\begin{array}{c}\text { Net cultivated } \\
\text { area }\end{array}$ & $\begin{array}{l}0.96 \\
(100)\end{array}$ & $\begin{array}{c}1.79 \\
(97.17)\end{array}$ & $\begin{array}{c}3.01 \\
(96.40)\end{array}$ & $\begin{array}{c}4.63 \\
(94.88)\end{array}$ & $\begin{array}{c}10.00 \\
(90.00)\end{array}$ & $\begin{array}{c}2.59 \\
(95.77)\end{array}$ \\
\hline 3 & $\begin{array}{l}\text { Permanent } \\
\text { fallow }\end{array}$ & - & $\begin{array}{c}0.02 \\
(1.42)\end{array}$ & $\begin{array}{c}0.05 \\
(1.60)\end{array}$ & $\begin{array}{c}0.15 \\
(3.07)\end{array}$ & - & $\begin{array}{l}0.047 \\
(1.73)\end{array}$ \\
\hline 4 & Current fallow & - & $\begin{array}{c}0.03 \\
(1.89)\end{array}$ & $\begin{array}{l}0.063 \\
(2.00)\end{array}$ & $\begin{array}{c}0.10 \\
(2.05)\end{array}$ & $\begin{array}{c}1.20 \\
(10.00)\end{array}$ & $\begin{array}{l}0.070 \\
(2.59)\end{array}$ \\
\hline
\end{tabular}

(Figure in parenthesis indicate the percentage to total land holding)

Table.7 Distribution of farmers according to the sources of irrigation

\begin{tabular}{|c|c|c|c|c|c|c|c|}
\hline \multirow{2}{*}{$\begin{array}{l}\text { Sr. } \\
\text { No. }\end{array}$} & \multirow{2}{*}{$\begin{array}{l}\text { Sources of } \\
\text { irrigation }\end{array}$} & \multicolumn{6}{|c|}{ Percent response } \\
\hline & & $\begin{array}{c}\text { Marginal } \\
(\mathbf{n}=25)\end{array}$ & $\begin{array}{c}\text { Small } \\
(\mathrm{n}=23)\end{array}$ & $\begin{array}{l}\text { Semi medium } \\
\text { to } \\
\text { medium }(n=24)\end{array}$ & $\begin{array}{c}\text { Medium } \\
(n=16)\end{array}$ & $\begin{array}{c}\text { Large } \\
(n=2)\end{array}$ & $\begin{array}{c}\text { Total } \\
(\mathbf{n}=90)\end{array}$ \\
\hline 1 & Open well & 16.00 & 43.48 & 29.17 & 50.00 & 0.00 & 32.22 \\
\hline 2 & Tube well & 0.00 & 17.39 & 16.67 & 0.00 & 0.00 & 8.89 \\
\hline 3 & River lifting & 0.00 & 4.35 & 25.00 & 6.25 & 0.00 & 8.89 \\
\hline 4 & Nala & 8.00 & 21.74 & 20.83 & 18.75 & 0.00 & 16.67 \\
\hline 5 & Pond & 0.00 & 0.00 & 4.17 & 0.00 & 0.00 & 8.33 \\
\hline 6 & Rent & 40.00 & 8.70 & 0.00 & 0.00 & 0.00 & 13.33 \\
\hline
\end{tabular}

(Figure in parenthesis indicate the percentage to total land holding)

Table.8 Distribution of farmers according to sources of fuel availability

\begin{tabular}{|c|c|c|c|c|c|c|c|}
\hline Sr. & Livestock & \multicolumn{5}{|c|}{ Percent response } \\
No. & Status & $\begin{array}{c}\text { Marginal } \\
(\mathbf{n = 2 5})\end{array}$ & $\begin{array}{c}\text { Small } \\
(\mathbf{n = 2 3})\end{array}$ & $\begin{array}{c}\text { Semi medium to } \\
\text { medium } \\
(\mathbf{n = 2 4})\end{array}$ & $\begin{array}{c}\text { Medium } \\
(\mathbf{n = 1 6})\end{array}$ & $\begin{array}{c}\text { Large } \\
(\mathbf{n = 2})\end{array}$ & $\begin{array}{c}\text { Total } \\
(\mathbf{n = 9 0})\end{array}$ \\
\hline $\mathbf{1}$ & $\begin{array}{c}\text { Crop } \\
\text { Residue }\end{array}$ & 84 & 91.30 & 95.83 & 93.75 & 100 & 91.11 \\
\hline $\mathbf{2}$ & $\begin{array}{c}\text { Cowdung } \\
\text { cake }\end{array}$ & 28 & 39.13 & 37.5 & 56.25 & 100 & 40 \\
\hline $\mathbf{3}$ & $\begin{array}{c}\text { Own tree } \\
\text { Collect } \\
\mathbf{4}\end{array}$ & 16 & 39.13 & 50 & 50 & 100 & 38.88 \\
\hline & $\begin{array}{c}\text { from } \\
\text { forest }\end{array}$ & & 73.91 & 79.16 & 75 & 50 & 80 \\
\hline
\end{tabular}


Table.9 Distribution of farmers according to the sources of energy use

\begin{tabular}{|c|c|c|c|c|c|c|c|}
\hline Sr. & Sources of & \multicolumn{6}{|c|}{ Percent response } \\
\cline { 3 - 8 } No. & energy & $\begin{array}{c}\text { Marginal } \\
(\mathbf{n = 2 5})\end{array}$ & $\begin{array}{c}\text { Small } \\
(\mathbf{n = 2 3})\end{array}$ & $\begin{array}{c}\text { Semi medium } \\
\text { to medium } \\
(\mathbf{n = 2 4 )}\end{array}$ & $\begin{array}{c}\text { Medium } \\
(\mathbf{n = 1 6})\end{array}$ & $\begin{array}{c}\text { Large } \\
(\mathbf{n = 2})\end{array}$ & $\begin{array}{c}\text { Total } \\
(\mathbf{n = 9 0})\end{array}$ \\
\hline $\mathbf{1}$ & Electricity & 68.00 & 60.87 & 66.67 & 56.25 & 50.00 & 63.33 \\
\hline $\mathbf{2}$ & $\begin{array}{c}\text { Solar } \\
\text { energy }\end{array}$ & 20.00 & 21.74 & 4.17 & 25.00 & 50.00 & 17.78 \\
\hline $\mathbf{3}$ & Gobar gas & 0.00 & 4.35 & 0.00 & 6.25 & 0.00 & 2.22 \\
\hline $\mathbf{4}$ & Kerosene & 88.00 & 95.65 & 91.67 & 87.50 & 100.00 & 91.11 \\
\hline $\mathbf{5}$ & LPG gas & 28.00 & 17.39 & 33.33 & 25.00 & 0.00 & 25.56 \\
\hline
\end{tabular}

Table.10 Distribution of farmers according to the agro forestry practices

\begin{tabular}{|c|c|c|c|c|c|c|c|}
\hline Sr. & Agroforestry & \multicolumn{5}{|c|}{ Percent response } \\
\cline { 3 - 7 } & practices & $\begin{array}{c}\text { Marginal } \\
(\mathbf{n = 2 5})\end{array}$ & $\begin{array}{c}\text { Small } \\
(\mathbf{n = 2 3})\end{array}$ & $\begin{array}{c}\text { Semi } \\
\text { medium } \\
\text { to medium } \\
(\mathbf{n = 2 4 )}\end{array}$ & $\begin{array}{c}\text { Medium } \\
(\mathbf{n = 1 6})\end{array}$ & $\begin{array}{c}\text { Large } \\
(\mathbf{n = 2})\end{array}$ & $\begin{array}{c}\text { Total } \\
(\mathbf{n = 9 0})\end{array}$ \\
\hline $\mathbf{1}$ & $\begin{array}{c}\text { Bund } \\
\text { planting }\end{array}$ & 68.00 & 65.22 & 66.67 & 75.00 & 100.00 & 68.89 \\
\hline $\mathbf{2}$ & $\begin{array}{c}\text { Boundary } \\
\text { planting }\end{array}$ & 44.00 & 56.52 & 58.33 & 93.75 & 50.00 & 60.00 \\
\hline $\mathbf{3}$ & $\begin{array}{c}\text { Scattered } \\
\text { planting }\end{array}$ & 8 & 21.73 & 16.66 & 31.25 & 0 & 17.77 \\
\hline $\mathbf{4}$ & $\begin{array}{c}\text { Agri- } \\
\text { horticulture }\end{array}$ & 0 & 4.34 & 0 & 12.5 & 0 & 3.33 \\
\hline $\mathbf{5}$ & $\begin{array}{c}\text { Block } \\
\text { plantation }\end{array}$ & 0 & 0 & 8.33 & 0 & 0 & 2.22 \\
\hline $\mathbf{6}$ & Home garden & 24 & 39.13 & 29.16 & 18.75 & 50 & 28.88 \\
\hline
\end{tabular}


Fig.1 Distribution of farmers according to size of land holding

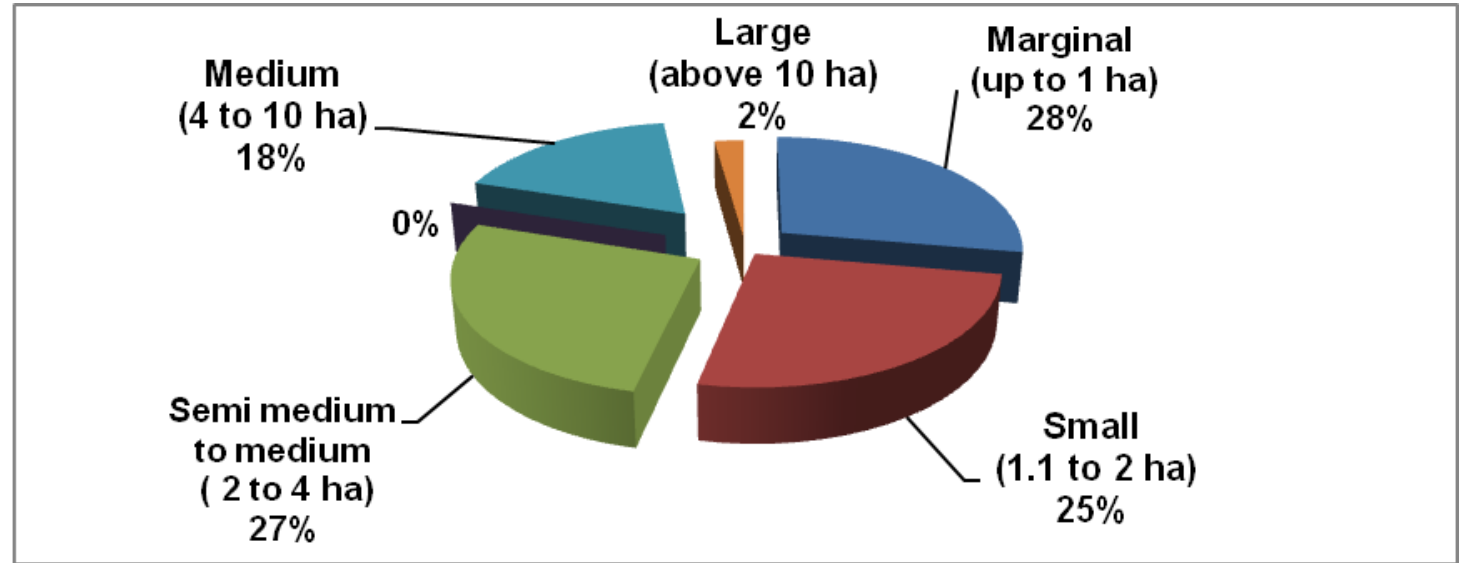

Fig.2 Distribution of farmers according to their age

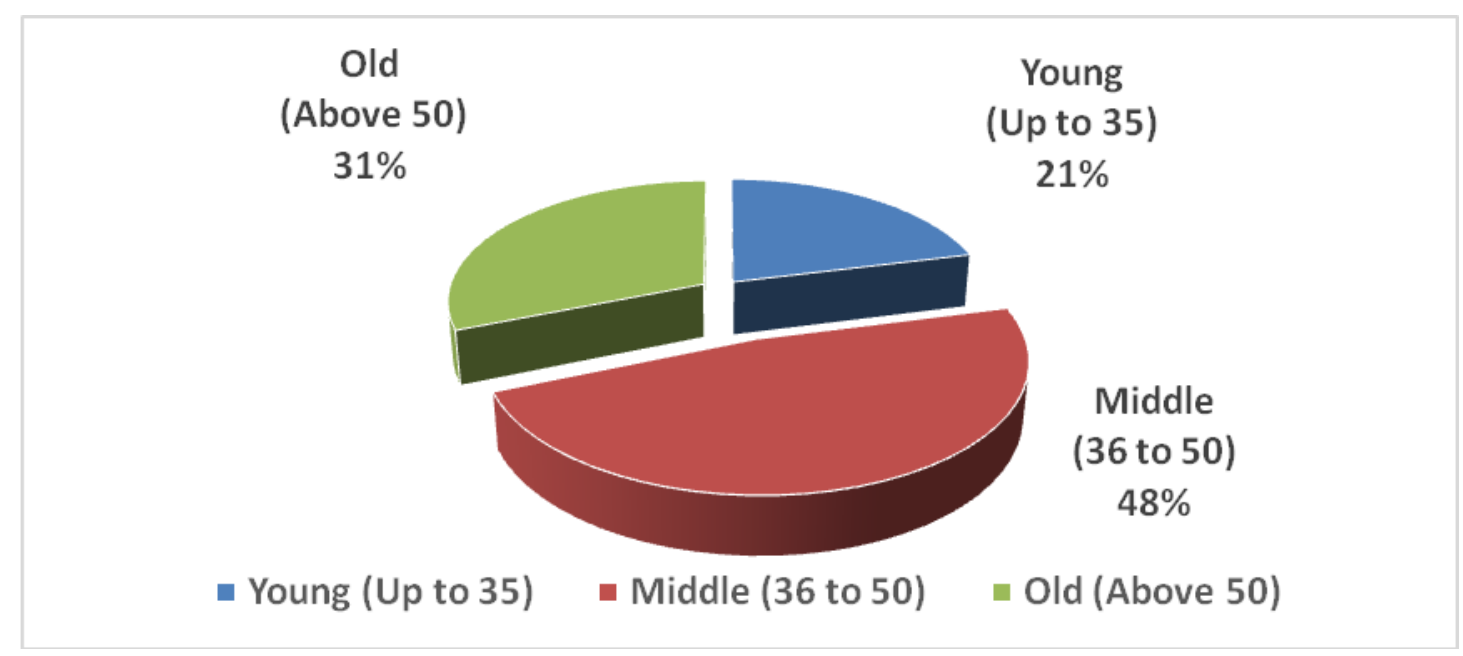

Fig.3 Distribution of farmers according to their educational level

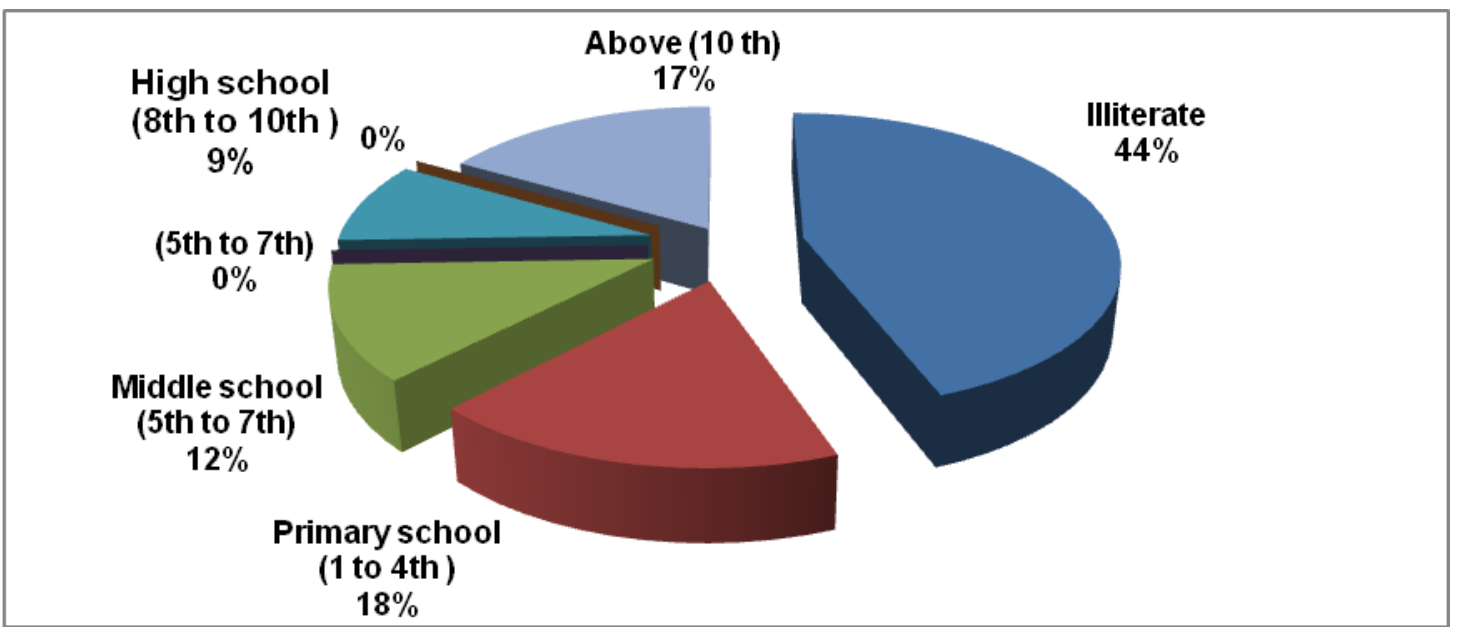


Fig.4 Distribution of farmers according to the sources of irrigation

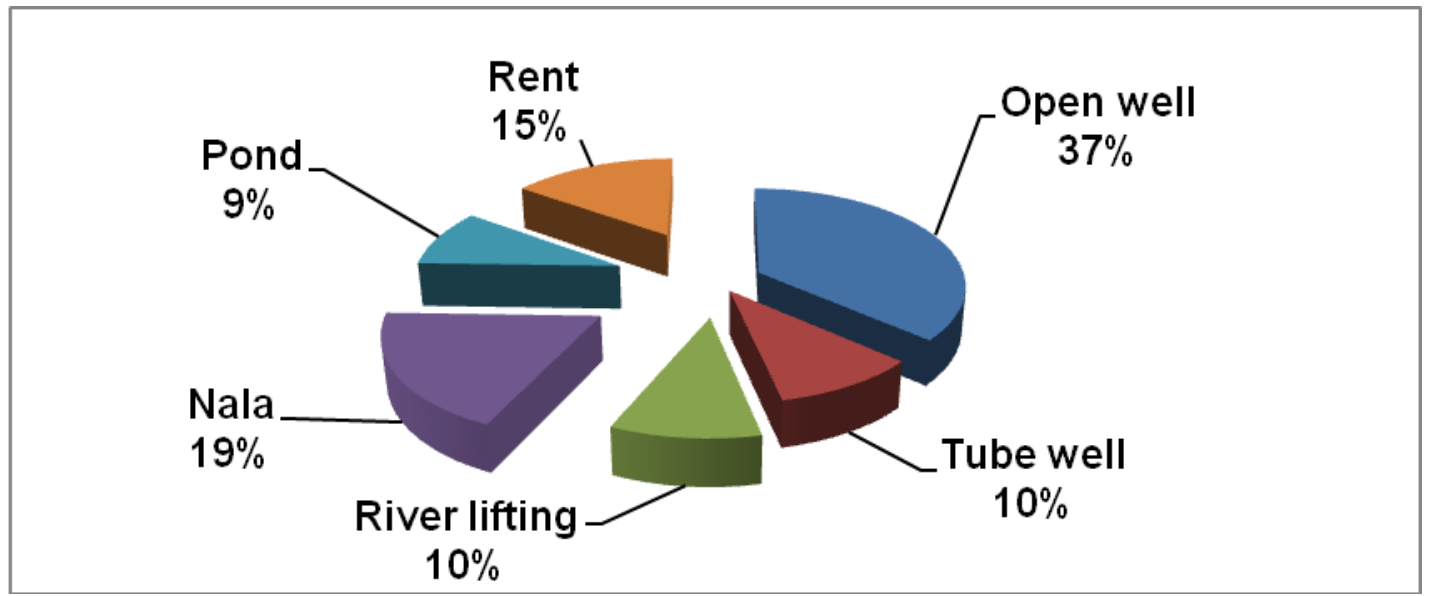

Fig.5 Distribution of farmers according to sources of fuel availability

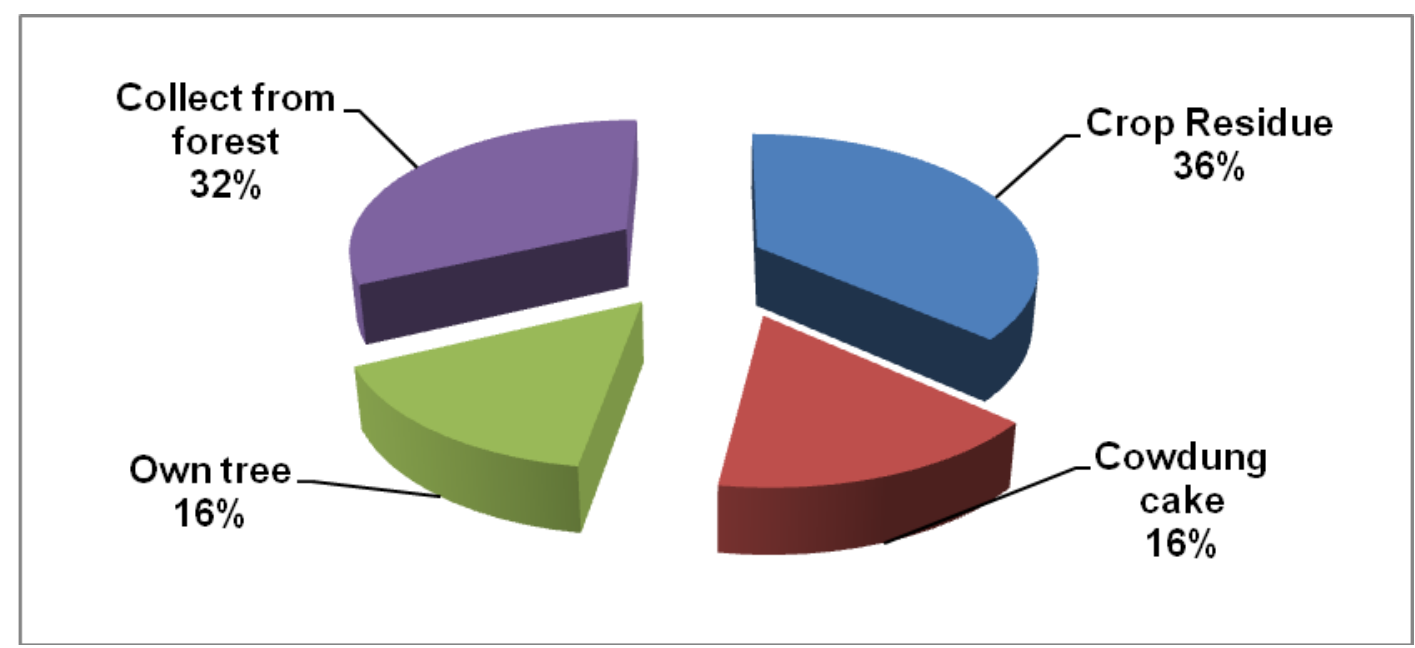

Fig.6 Distribution of farmers according to the sources of energy use

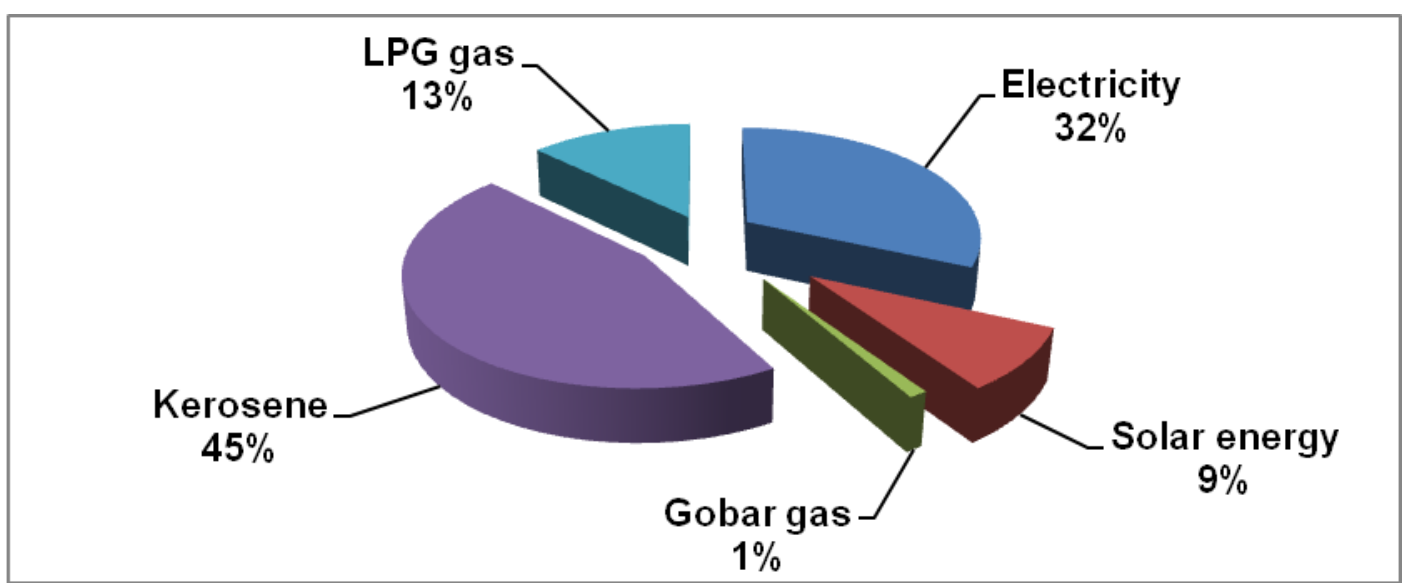


Fig.7 Distribution of farmers according to the agroforestry practices

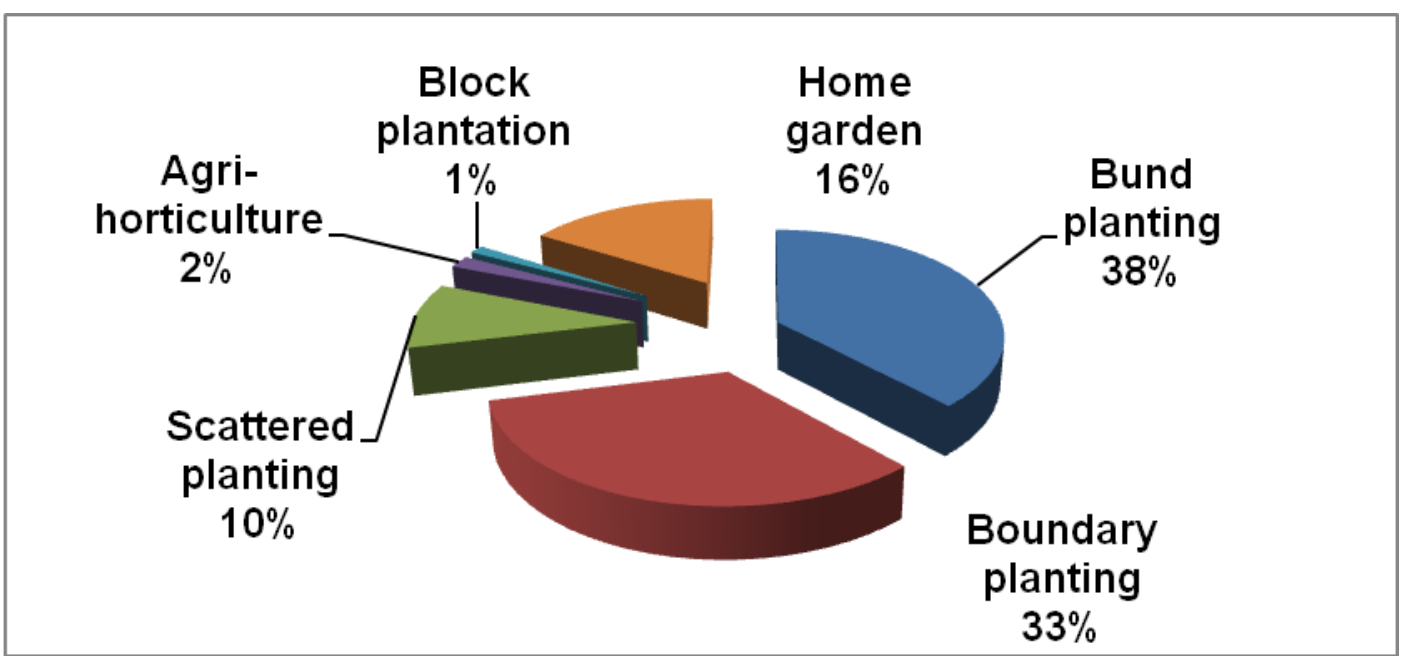

In the semimedium farmers group, 29.17per cent farmers having open well, 25.00percent farmers using river lifting, 20.83 percent farmers using nala lifting, 4.17 per cent farmers are using water pond, 16.67 per cent using tube well. Melghat have some seasonal rivers and nala are active with flow of water in monsoon season, some farmers utilize them as source of irrigation.

\section{Sources of fuel in study area}

The fuel wood was being used by all the families in different villages beside the other alternatives. The fuel wood was mainly used for cooking and water heating during winter. However, the families with better economic condition were also using kerosene and LPG. The fuel wood consumption was met from the adjoining natural forests and the trees available in their agricultural fields (traditional agroforestry systems).

Table 8 and depicted in fig. 5. shows that, overall 91.11 per cent farmers fulfill their fuel need by collection of fuel wood from farm land that is agri-waste like tur stalk, jowar stubble etc. followed by collection of fuel wood from forest $(80 \%)$, cow dung (40.00 $\%$ ), fuel wood from own tree present on farms
$(38.88 \%)$. All marginal land holding farmer near about (92\%) collected fuel wood from government forest. The inhabitants in Melghat are mainly tribal; largely of the Korku others like Gond, Nihal etc. which heavily depend on the forest to fulfill need of fuel wood apart from timber, fodder and other minor forest produce. Chauhan et al., (1990) reported that the main source of fuel wood in Vidarbha is forest near villages and farmers spent lot of time and money on collected of fuel wood. Forest was considered as main source of fuel wood. The total contribution of forest in meeting the fuel wood needs was 53 per cent; villagers own source (homestead and farm land) contributed 26 per cent in India.

\section{Sources of energy use in study area}

The source of energy was used by all the families in different villages beside the other alternatives. The source of energy was mainly used for cooking and water heating during winter. However, the families with better economic condition were also using kerosene, LPG and bio-gas. The solar energy was use where electricity was not available in that village or in the adjoining natural forests area. Table 9 and depicted in fig. 6 shows that, overall 91.11 percent farmers use kerosene as 
source of energy kerosene followed by electricity (63.33\%), LPG gas (25.56\%), solar energy (17.78\%) and gobar gas (2.22\%). Among marginal land holding farmer $(88.00 \%)$ use kerosene and electricity (68.00) and no even single farmer use gobar gas. The inhabitants in Melghat are mainly tribal, largely of the Korku others like Gond, Nihal etc. which heavily depend on solar energy for fulfill their need because some village are in forest area where there is unavailability of electricity.

\section{Agroforestry systems followed by farmers in Chikhaldhara}

The data on prominent agroforestry practices followed by farmers in Chikhaldara is given in table 10 and depicted in fig. 7.

Melghat is predominantly a (soybean-wheat) and (sorghum + tur) cropping zone with inadequate irrigation facilities. The multipurpose trees are present in the farm fields on a scattered basis with greater concentration on the field bunds and boundaries. In the present investigations it was observed that plantation of different kinds of tree species along field bunds, boundary, scattered planting, home garden etc. was a common practices throughout the Melghat. The cultivation of tree species in association with agricultural crops grouped into seven different type's viz. bund planting, boundary planting, scattered planting, agri-horti-silviculture, agrihorticulture, block plantation and home gardens. Overall in Chikhaldara bund planting was the major agroforestry practice $(68.89 \%)$ Followed by the boundary planting $(60.00 \%)$, home gardens (28.88\%), scattered planting (17.77\%) and Agri-horticulture (3.33) were also practiced by majority of farmers. Agroforestry systems like block plantation and agri-horticulture were practiced by limited number of farmers in both rainfed and irrigated agro-forestry in Melghat (response <
$10 \%)$. The bund planting was found to be most prominent agroforestry practice both in rainfed and irrigated situations. Ilorkar (2007) and Chauhan et al., (1990) also reported bund planting is prominent agroforestry practice in Vidharbha region. The bund planting and boundary planting were prominent in study area. The scattered planting was highest $(31.25 \%)$ in medium land holding farmers.

Devaranavadgis et al., (2010) and Madiwalar et al., (2007) also reported scattered planting, bund planting and boundary planting as prominent agroforestry systems. The dominance of scattered planting, bund planting and boundary planting may be due to relatively lesser rainfall.

It can be concluded that, Melghat region, which is located in the physiographic unit i.e. eroded valley and hilly region developed on basalt, land was slopy and undulating with the elevation of 320 - 1100 meters above mean sea level. Korku is the dominant tribes inhabited adjoining to forest regain. The majority of tribal farmers in Chikhaldara tehasil were marginal to small land holder and dependent on rainfed agriculture. Traditionally they are practicing bund and livestock farming systems for sustainance. Illiteracy and poor institution is the bottleneck of this tribal region.

\section{References}

Adhau, B. P., 2015. Study on the effect of socio - economic parameters on health status of the Gond, Bhill, Korku tribes of Amravati division in Maharashtra. Online International Interdisciplinary Research Journal, pp. 209.

Bhogaonkar, P. Y., V. R. Marathe and P. P. Kshirsagar, 2010. Documentation of wild edible plants of Melghat forest dist. Amravati, Maharashtra State, India. Ethnobotanical Leaflets 14: 751- 
58.

Chauhan, P. S., P. O. Ingle, B. J. Jadhao and R. B. Ulemale, 1990. Appraisal of agroforestry practices in Vidarbha region of Maharashtra state. $P K V$ Research Journal. 14(1): 80-83.

Devaranavadgis, S. B., S. Wali, S. Patil, M. Jambagi and D. Kambrekar, 2010. Survey of traditional agroforestry systems practiced in northern dry tract of Karnataka. Karnataka. J. Agric. Sci., 23 (2): 277-281.

Dwivedi, R. P., K. Kareemulla, R. Singh, R. H. Rizvi and J. Chauhan, 2007.Socioeconomic analysis of agroforestry systems in Western Uttar Pradesh. Indian Res. J. Ext. Edu. 7 (2\&3): 1822.

FSI, 2013. Trees in agroforestry system, India state forest report. Forest Survey of India, Dehradun: 71-80.

Ilorkar, V. M., 2007. Agroforestry systems in Maharashtra. Agroforestry systems and practices. New India publishing agency. Pp. 267-275.

Madiwalar, S., L. Channabasappa and R. Deshmukh, 2007. Survey and documentation of agroforestry models in Bidar, Gulbarga and Raichur Districts. Karnataka J. Agric. Sci., 20(1): 93 - 95.

Singh, R., 1. 1. Simte and T. H. R. Singh, 1996. Existing agroforestry systems and practices in Manipur. Indian Forester, July. Pp. 598-603.

Verma, D. P. S., 1990. Agroforestry practices of Gujarat state. International Tree Crops Journal, 6(1): 17-30.

\section{How to cite this article:}

Zalte, S. G., S. M. Bhoyar and Deshmukh, P. W. 2021. Assessment of Socio Economics Status of Tribal Farmers in Chikhaldara Tehasil of Amravati District. Int.J.Curr.Microbiol.App.Sci. 10(02): 2655-2666. doi: https://doi.org/10.20546/ijcmas.2021.1002.291 